\title{
ОСОБЕННОСТИ РЕПРЕЗЕНТАЦИИ ВОЕННОЙ ТЕРМИНОЛОГИИ В ХОДЕ ОБУЧЕНИЯ НЕМЕЦКОМУ ЯЗЫКУ В ВОЕННОМ ВУЗЕ
}

\section{FEATURES OF THE REPRESENTATION OF MILITARY TERMINOLOGY \\ IN THE COURSE OF TEACHING GERMAN AT A MILITARY UNIVERSITY}

L. Vasilenko

Summary: Modern processes of globalization require a revision of approaches to teaching a foreign language at all levels. In particular, it is necessary to take a fresh look at the representation of German military terminology in the course of teaching German as a foreign language in Russian military universities. This is the relevance of this work. The purpose of this study is to identify and summarize at the modern level the ideas of the representation of military terminology in the course of teaching German at a military university. A certain novelty of the research is associated with a combination of ideas of the classical approach to the study of language, foreign terms and innovative culturological views in the field of teaching foreign languages, taking into account the development of modern technology.

Keywords: teaching German; professional vocabulary; features of term representation; military terminology; military university; foreign language.
Д ля военной терминологии характерно стремительное расширение и обновление: это обусловлено тем, что на сегодняшний день военная сфера вивающихся областей человеческой деятельности, где постоянно разрабатываются новейшие военные технологии, создаются различные виды вооружения нового поколения, осуществляется модернизация уже существующего военного оружия, боевой техники и пр. [15]. В связи с этим крайне важно исследование специфики репрезентации военной терминологии в ходе изучения иностранного языка (в данном случае - немецкого). При этом особый интерес вызывает исследование репрезентации терминов в рамках обучения языку в военном вузе, поскольку специфика учебного процесса в военном вузе предполагает сочетание «военно-профессиональной подготовки и подготовки специалиста в соответствии с государственными стандартами высшего образования» $[12$, с. 40]. Т.е. основное отличие от традиционного «университетского образования» заключается в том, что в военном вузе обучение проходит одновременно с действительной военной службой. Так, в ходе обучения немецкому языку, кроме формирования определенных компетенций (учебно-познавательной,
Василенко Любовь Юрьевна

Дочент, Общевойсковая ордена Жукова академия Вооруженных Сил Российской Федерации (2. Москва) bag87@mail.ru

Аннотация: Современные процессы глобализации требуют пересмотра подходов к преподаванию иностранного языка на всех уровнях. В частности, необходимо по-новому взглянуть на репрезентацию немецкой военной терминологии в курсе преподавания немецкого языка как иностранного в российских военных высших учебных заведениях, что и составляет актуальность данной работы. Цель данного исследования - выявить и обобщить на современном уровне идеи репрезентации военной терминологии в ходе обучения немецкому языку в военном вузе. Определенная новизна исследования связана с сочетанием идей классического подхода к изучению языка, иностранных терминов и новаторских культурологических воззрений в области преподавания иностранных языков, с учетом развития современной техники.

Ключевые слова: обучение немецкому языку; профессиональная лексика; особенности репрезентации терминов; военная терминология; военный вуз; иностранный язык.

коммуникативной и пр.), слушатели военного вуза получают и развивают знания и навыки, связанные с военной сферой, что, безусловно, следует учитывать при выборе методики обучения немецкому языку, в рамках которой осуществляется репрезентация военной терминологии.

На сегодняшний день при изучении иностранного языка в вузе активно используется так называемый лингвострановедческий подход. По мнению целого ряда ученых, данный подход позволяет подготовить высококвалифицированных специалистов с ориентацией на новейшее научное знание, открытых к восприятию современных научных достижений, профессиональному и межкультурному диалогу [7; 11; 18]. Лингвострановедческий подход на современном этапе очень важен: соответствующий термин, возникнув относительно недавно, в 1970-е гг., применительно к сфере преподавания русского языка как иностранного, был использован во многих научных исследования, развивающих страноведческую концепцию преподавания иностранного языка (Е.М. Верещагин, А.Д. Верисова, В.Г. Костомаров, Р.К. Миньяр-Белоручев, Л.Г. Морозкина, В.П. Фурманова, C. Földes, H. Hammerly, H. Herde, E. Hirsch, H. Uhleman и др. [3]). Однако, на наш взгляд, использование данного под- 
хода в рамках обучения слушателей немецкому языку в военном вузе будет более эффективным, если его совместить с рядом других современных подходов (коммуникативным, этимологическим, концептуальным и пр.). Все это позволит слушателям не только получить различные языковые знания и навыки, но и сформировать определенные представления о тех или иных объектах, явлениях военной сферы на базе изучаемой терминологии, а также выявить особенности ее репрезентации.

Прежде чем перейти к рассмотрению особенностей репрезентации военной терминологии в ходе обучения немецкому языку в военном вузе, следует отметить, что под терминами (терминологией) понимаются «слова или словосочетания, которые являются наименованиями каких-либо специализированных понятий, относящихся к сфере науки, техники, искусства, культуры или любой другой профессиональной сферы деятельности человека, знаниями в области которой обладает ограниченный круг людей» [1, с. 29-30]. Соответственно, военная терминология представляет собой формализованную систему военных терминов (слов, словосочетаний и т.д.), каждый из которых обладает строго очерченным значением с четко установленными рамками использования и научным обоснованием [6]. Репрезентация немецкой военной терминологии обусловлена наличием ряда переводоведческих проблем. В силу специфики немецкого языка около 80\% всех немецких военных терминов являются сложными словами (словосложение, как известно, весьма характерно для немецкого языка, в области же военных терминов - это «один из основных способов образования слов в рамках данной лингвистической системы») [13, с. 177]. Следовательно, в рамках обучения немецкому языку весьма важно обращать особое внимание слушателей на соотнесение русских словосочетаний и немецких сложных лексем. В частности, следует учитывать, что многие немецкие военные термины переводятся на русский разъяснительными словосочетаниями:

— Gepäckkraftwagen - грузовой автомобиль для личных вещей военнослужащих;

- Generalstabsoffizier - офицер службы генерального umaбa (ФРГ);

- Marinestreitkräfte - военно-морские силы; боевые силы (флота);

- Hochseeflotte - океанский флот, флот открытого моря;

- Streitkräfte - вооруженные силы (государства) [14].

Отдельный акцент в ходе обучения немецкому языку в военном вузе следует делать на представлении усеченных терминов - словосочетаний [5]. Речь идет о словах, несущих информацию о многофункциональных понятиях, охватывающих одновременно не один, а два и более совершенно разных объектов действительности. В данном случае в качестве обязательного элемента присутствует союз und:
- Panzerbrand- und Leuchtspurgeschob - бронебойнозажигательный трассирующий снаряд (пуля);

- Stabs- und Versorgungskompanie - poma штабная и снабжения [14].

Кроме того, следует выделять сокращенные военные термины, которые образовались из распространенных терминологических выражений:

- U-Boot- подводная лодка;

- ABC (atomar, biologisch und chemisch) - противоядерный, противобиологический и противохимический; относящийся к оружию массового поражения;

- Az.o.V. (Aufschlagzünder ohne Verzögerung) - yдарный взрыватель мгновенного действия [14].

Заметим и то, что для терминологии, о которой идет речь, весьма характерно наличие «безэквивалентных терминов-реалий» [7, с. 19], обозначающих специфические военные понятия, отсутствующие в русской военной действительности:

- Stammkommando - командование данного класса (кораблей);

- Stammrolle - именной список личного состава [14] (подобные лексемы переводятся, как правило, описательно).

В ходе обучения немецкому языку в военном вузе также весьма важно обращать внимание на этимологию (помогающую, в конечном итоге, «предсказывать» изменения, «вариации значения термина на современном этапе» [10, с. 139]), на взаимное влияние терминологии разных стран. Для правильного перевода, понимания устной или письменной речи в данном случае требуется знание профессиональной сферы, понимание контекста [9]. Таким образом, требуется соответствующая методика, многие элементы которой разработаны и могут быть уточнены, дополнены с позиций коммуникативного подхода (не исключающего грамматический и иные традиционные подходы к преподаванию немецкого языка), современных технических средств, используемых в процессе обучения [16]. В частности, этимологические процессы, внимание к которым необходимо при освоении немецких военных терминов, разумеется, могут быть освоены через специально подобранные интернет-материалы (впоследствии блиц-анализ этимологического характера при переводе будет осуществляться автоматически, этому поможет немалый объем этимологических статей, которые способен переработать современный слушатель с учетом возможностей Интернета).

С целью репрезентации военной терминологии на занятиях по немецкому языку в военном вузе могут быть сформированы видеоподборки, демонстрирующие настоящие и исторические немецкие военные реалии, что само по себе важно при изучении любого иностранного 
языка, так как помогает «наглядно-эмоционально воспринять денотат» [8, с. 101], тем более важны подобные приемы при изучении военной терминологии, обладающей набором определенных характеристик. Эффективным приемом также может стать демонстрация видеоматериалов, показывающих российские военные реалии. В качестве примера использования этимологического подхода можно привести термин Feldwebel / Фельдфебель:

- Feldwebel (m), XVI в. - фельдфебель, фельдвебель; ранее употреблялся в значении Unteroffizier (m) - сержант. Происходит от ранненововерхнеro. feldweibel. C XVI в. употреблялся в значении Weibel - Gerichtsdiener - т.е. судебный пристав, служащий на поле боя. Гласная е указывает на восточно-средненемецкий вариант [17];

- Фельдфебель - в русской (до 1917) и некоторых иностранных армиях звание старшего из унтерофицеров (кроме кавалерии), непосредственного помощника командира роты (батареи) по административным и хозяйственным вопросам и его заместителем в отсутствие офицеров [5]. Следовательно, такой человек мог считаться старшиной, прапорщиком. Этимологическое исследование показывает, что изначальное значение термина сержант, позднее термин приобретает значение старшина, прапоршик.

Слушатели военных вузов, изучающие терминологию в курсе немецкого языка, должны осознавать, что, кроме собственно словарного перевода, возможен перевод с использованием справочников, монографий, документов, статей, консультаций со специалистами. В качестве переводческих приемов возможны грамматические и лексические трансформации, а также «лексико-семантические, лексико-грамматические трансформации» [4, с. 128]. Говоря об использовании целого комплекса подходов (среди которых: лингвострановедческий, коммуникативный, когнитивный и пр.) при обучении немецкому языку слушателей военных вузов, следует отметить, что ведущими задачами являются: отражение фоновых знаний (военно-профессиональных реалий (экзотизмов), коннотативной и фоновой лексики); невербальных языков повседневного поведения, наиболее ярко отражающих национальные особенности; формирование лингвострановедческой и коммуникативной компетенции слушателей и др. При этом рекомендуется не заострять чрезмерного внимания на изучении безэквивалентной лексики и прочих лингвокультурологических аспектов обучения слушателей немецкому языку. Для этого, как справедливо отмечают Н.А. Гуляева и О.Н. Проценко, целесообразно отводить не более 15-20 минут аудиторного времени [3].

Внедряя современные методики обучения немецкому языку, в рамках которых осуществляется репре- зентация военной терминологии, следует достаточно скрупулезно подойти к выбору современных учебных и справочных пособий, в т.ч. словарей военной терминологии. Современные словари, как правило, отличаются разноплановым и достаточно широким материалом, полученным не только из других печатных источников, но и также из СМИ и Интернет-ресурсов. В качестве примера можно привести словарь Н.А. Гуляевой [2], где представлены устные военные команды и доклады, не всегда совпадающие в двух языках: немецком и русском. Также словарь отличается красочно оформленным языковым и иллюстративным материалом, который, вероятно, имеет потенциал языкового совершенствования в лингвострановедческом и культурологическом аспектах (особенно с учетом использования электронных интерактивных изданий, начинающих разрабатываться и распространяться в образовательной сфере [7, с. 19]). Приведем наиболее яркие примеры из словаря Н.А. Гуляевой:

- Feuer und Flamme sein - загореться чем-нибуды, страстно желать чего-либо, но не «быть огнем и пламенем»;

- Großer Heinrich - Большой Генрих / Der blanke Hans Сверкающий (Блестящий) Ганс - прозвища Северного моря;

- weiße Hunde - белые барашки на волнах во время приближения иторма, но не «белые собачки/собаки»;

- Vater Rhein - Батюшка Рейн (разг. название Рейна, по аналогии с выражением «Батюшка Байкал»);

- das nasse Dreieck - Мокрый треугольник (треугольник германских крепостей в Северном море: Cuxhaven, Wilhelmshaven, Helgoland, передовой пункт треугольника - о. Гельголанд);

- Hundstage - ужасная/невыносимая жара (у русскоязычных ассочиачия с «африканской жарой» (простореч.)) и др. [2].

Материал словаря Н.А. Гуляевой размещен в соответствующие разделы, снабжен переводом и практической транскрипцией на русском языке. В указанном словнике имеются пояснения к военным командам и докладам, не принятым в двух языках: немецком и русском. Есть раздел, специально посвященный эмоционально окрашенным выражениям. Например, в разделе команд в словаре имеются следующие:

— Im halber Schritt, marsch! - Короче шаг! (но не «Вполшага, марu!»);

- Gewehr um den Hals! - Оружие на грудь! (но не «Оружие на шею!»);

- Augen links! - Равнение налеВО! (но не «Глаза налево!»);

- Dali, Dali! - Живее! (В подражание итальянскому. Двойное повторение для ускорения действия) [2].

Таким образом, рассмотрев особенности репрезентации военной терминологии в ходе обучения немецкому 
языку в военном вузе, приходим к выводу, что большое значение имеет выбор методик, в рамках которых осуществляется репрезентация военных терминов, а также учебного и наглядного материала, в т.ч. словарей военной терминологии. В частности, целесообразно использовать комплекс методик и подходов, среди которых: лингвострановедческий коммуникативный, этимологический и др., позволяющие слушателям военных вузов не только получить различные языковые знания и навыки, но и сформировать определенные представления об объектах, предметах, явлениях, связанных с военной сферой. Что касается учебного и наглядного материала, военных словарей и справочников, то к их выбору следует подойти скрупулезно, поскольку от этого зависит качество получаемых языковых знаний и навыков. При этом следует учитывать, что большое количество современных словарей (учебных пособий) вмещает в себя достаточно обширную и разноплановую информацию по военной тематике. Все это, безусловно, способствует развитию более эффективных методик обучения немецкому языку в рамках изучения военной терминологии, ее репрезентации и развития в современных условиях.

\section{ЛИТЕРАТУРА}

1. Гринев-Гриневич С.В. Терминоведение: учебное пособие для студентов вузов / С.В. Гринев-Гриневич. М.: Издательский центр «Академия», 2008.304 с.

2. Гуляева Н.А. Немецко-русский карманный словарь устных военных команд и докладов = Deutsch-russisches Taschenbuch für Militärbefehle- und Meldungen: учеб. пособие. Новосибирск: НВВкУ, 2017. 134 с.

3. Гуляева Н.А. Элементы профессионального военного лингвострановедения на занятиях по иностранному языку в военном вузе / Н.А. Гуляева, 0.Н. Проценко // Сибирский педагогический журнал. 2018. № 4. С. 75-84.

4. Гусева А.И. Специфика репрезентации военной терминологии в переводе / А.И. Гусева // Культура народов Причерноморья. 2014. № 271. С. 127-130.

5. Дуброва Ю.Ю. Структурно-содержательная специфика многокомпонентных терминов: на материале военных документов: автореф. дис. ... канд. филолог. наук: 10.02.19 / Ю.Ю. Дуброва. М: Моск. гос. лингвист. ун-т, 2015. 22 с.

6. К Кожанов Д.А. Новые подходы к определению сущности термина в когнитивно-дискурсивных исследованиях / Д. А. Кожанов // Мир науки, культуры, образования, 2008. № 5(12). С. 43-47.

7. Колесникова А.Ю. Особенности изучения военной терминологии по иностранному языку в военном вузе / А.Ю. Колесникова, С.Г. Торосян // Научно-методический электронный журнал «Концепт». 2017. № S24. С. 18-22.

8. Лату М.Н. Военная терминология в современном политическом дискурсе / М.Н. Лату // Политическая лингвистика. 2011. № 3. С. 98-104.

9. Лейчик В.М. Терминоведение: предмет, методы, структура. 4-е изд. / В.М. Лейчик. М.: «Либроком», 2009. 256 с.

10. Макурина И.Ю. Военный текст: стратегии обучения переводу / И.Ю. Макурина // LINGUA MOBILIS. 2015, № 1(52). C. 137-140.

11. Соколов С.В. Развитие и современное состояние немецкоязычной военной лексики: автореф. дис. ... канд. филолог. наук: 10.02 .04 / С.В. Соколов. М.: Моск. пед. гос. ун-т, 2013. 18 с.

12. Соловей Д.В. Особенности образовательной среды военного вуза / Д.В. Соловей, В.И. Спирина // Вестник Армавирского государственного педагогического университета. 2019. №. 2. С. 36-43.

13. Стрелковский Г.М. Теория и практика военного перевода: Немецкий язык / Г.М. Стрелковский. М.: «Воениздат», 1979. 272 с.

14. Цвиллинг М.Я. Немецко-русский военно-морской словарь / сост. М.Я. Цвиллинг, Ю.А. Яхонтов, Л.И. Искрицкая [и др.]; под общ. ред. канд. воен.-мор. наук доц. кап. 1 ранга А.И. Бледнева. М.: Воениздат, 1961. 456 с.

15. Kraft, I. Militärische Multinationalität / I. Kraft // Bundeswehr. Zentrum für Militärgeschichte und Sozialwissenschaften. URL: https://www.bundeswehr.de/de/ organisation/weitere-bmvg-dienststellen/ zentrum-militaergeschichte-sozialwissenschaften/zmsbw-forschung-kraft-militaerische-multinationalitaet-91130 (15.02.2021).

16. Kutz M. Deutsche Soldaten. Eine Kultur und Mentalitätsgeschichte / M. Kutz. Darmstadt: Wissenschaftliche Buchgesellschaft, $2006.403 \mathrm{~s}$.

17. Reeb H.-J. Lexikon Innere Führung: Sämtliche Aspekte der Inneren Führung im Überblick / H.-J. Reeb, P. Többicke. Regensburg. Walhalla u. Praetoria Verlag GmbH \& C.2017. $149 \mathrm{~s}$.

18. Slater A. Militärsprache: die Sprachpraxis der Bundeswehr und ihre geschichtliche Entwicklung / A. Slater; unter Mitwirkung von Arno Fischer. Freiburg im Breisgau: Rombach, 2015. $275 \mathrm{~s}$. 